УДК 342.9-053.74

DOI https://doi.org/10.32849/2663-5313/2020.7.24

Дмитро Гурін, аспірант

Київського міжнародного університету

\title{
ПРАВОВИЙ СТАТУС ДЕРЖАВНОЇ МІГРАЦІЙНОЇ СЛУЖБИ В ЗАБЕЗПЕЧЕННІ РЕАЛІЗАЦІЇ ДЕРЖАВНОЇ ПОЛІТИКИ У СФЕРІ МІГРАЦІЇ
}

У статті досліджено розвиток та реорганізачію державних органів виконавчої влади, на які покладалися функиї з реалізащї державної політики у сфері мігращїі, та правовий статус державної міграчійної служби як иентрального органу виконавчої влади, який забезпечує реалізачію державної політики у сфері міграції в Україні.

Визначено, що реорганізачія органів державної влади з реалізачії державної політики у сфері міграції в Україні триває вже більше 10 років та вказує на необхідність створення та ефективного функиіонування окремого єдиного державного органу, який би зосередив у собі функиї̈ у сфері міграції, громадянства та імміграчії. Таким органом стала Державна міграиійна служба України.

Акцентовано увагу на порівняльному дослідженні правового статусу органів державної влади, які в період реорганізачії мали повноваження з реалізації державної політики у сферах міграчії (імміграиії та еміграції), у тому числі протидї нелегальній (незаконній міграції), громадянства, реєстрації фізичних осіб, біжениів та інших визначених законодавством категорій мігрантів.

Докладно досліджені права та обов'язки ДМС України як центрального органу виконавчої влади, діяльність якого спрямовується та координується Кабінетом Міністрів України через Міністра внутрішніх справ і який реалізує державну політику у сферах міграції (імміграчї̈ та еміграиії), у тому числі протидї нелегальній (незаконній міграчії), громадянства, реєстращії фізичних осіб, біженців та інших визначених законодавством категорій мігрантів.

Обгрунтовано необхідність розробки Закону України «Про Державну міграчійну службу». Звер нено увагу, що ДМС України визначається як служба, тому більшість ї̈ функиій повинно бути спрямовано на надання адміністративних послуг фізичним та юридичним особам. Шляхом аналізу повноважень на прикладі повноважень ДМС України з надання статусу біжения встановлено, що функиіі ДМС України у питаннях, пов'язаних із біжениями, можна визначити як надання адміністративних послуг з надання іноземиям та особам без громадянства статусу біжения.

Підсумовуючи зазначене, констатуємо, що тривалий розвиток та реорганізачія державних органів виконавчої влади, які відбулися з 1993 до 2014 років, довели необхідність створення та функиіонування ДМС України як иентрального органу виконавчої влади, який забезпечує реалізачію державної політики у сфері міграції, $і$ є основним органом, що безпосередньо здійснює адміністративні послуги з надання іноземиям та особам без громадянства статусу біжения.

Ключові слова: правовий статус, державні органи, міграційна політика, міграційна служба, біженець, правове регулювання, надання статусу.

Постановка проблеми. Державна міграційна служба України (далі - ДМС України) $є$ відносно молодим органом виконавчої влади, створеним у 2010 році на підставі указу Президента України від 09.12.2010 № 1085/2010 «Про оптимізацію системи центральних органів виконавчої влади» [1], проте ії становленню як центрального органу виконавчої влади, який забезпечує реалізацію державної політики у сфері міграції, передувала значна робота 3 формування та реорганізації органів виконавчої влади, на які так чи інакше покладалися функції у сфері міграції.
Метою статті $є$ дослідження розвитку та реорганізації державних органів виконавчої влади, на які покладалися функції 3 реалізації державної політики у сфері міграції.

Аналіз останніх досліджень і публікацій Окремі питання державної політики та нормативно-правового регулювання у сфері міграції розглядали у своїх роботах В. П. Босий, С .Г. Волкова, О. О. Воронятніков, Н. М. Грабар, М. О. Сфремова, I. І. Ковалишин, С. Ф. Константінов, О.В.Кузьменко, А. В. Максименко, Р.А. Мар- 
тьянова, Л. П. Пастухова, О. Н. Поворозник, Ю. В. Тодика, Ю. М. Тодика, О. Ю. Тодика, Р. О. Хоменець, А. Г. Шуміленко, проте з огляду на сьогодення ці питання потребують актуалізації.

Виклад основного матеріалу. У 1993 році на підставі Указу Президента України від 26.04.1993 № 145 створене Міністерство України у справах національностей та міграції [2], до повноважень якого, відповідно до постанови Кабінету Міністрів України від 26.06.1993 № 487, належала координація роботи центральних і місцевих органів державної виконавчої влади та органів міс цевого i регіонального самоврядування, пов'язана 3 розробкою та здійсненням заходів щодо тимчасового розміщення, працевлаштування, надання грошової допомоги та соціально-побутових і медичних послуг біженцям, а також організація їх обліку і реєстрації, вирішення інших питань, що виникали у зв'язку з прибуттям цих осіб на територію України [3]. Зазначене Міністерство функціонувало до червня 1996 року, коли відповідно до указу Президента України від 26.07.1996 № 596 «Про зміни в системі центральних органів виконавчої влади України» й було ліквідовано, а натомість утворено Державний комітет України у справах національностей та міграції [4]. Правовий статус зазначеного комітету визначався Положенням про Державний комітет України у справах національностей та міграції, затвердженим Указом Президента України від 28.10.1996 № 1001/96. Відповідно до цього Положення Комітет мав згідно з покладеними на нього завданнями забезпечувати реалізацію прав і соціальних гарантій біженців, координувати взаємодію органів виконавчої влади під час розв'язання проблем біженців відповідно до законодавства України та вести централізований облік біженців та осіб, які звернулися із заявою про надання статусу біженців [5].

У результаті подальшої реорганізації структури центральних органів виконавчої влади, що відбулася на підставі Указу Президента України від 15.12.1999 № 1573/99, Державний комітет України у справах національностей та міграції було ліквідовано, а повноваження 3 надання організаційнометодичної допомоги відповідним органам та підрозділам у реалізації прав і соціальних гарантій біженців, внесення пропозицій щодо вирішення питань про надання чи позбавлення статусу біженця, ведення централізованого обліку біженців та осіб, які звернулися із заявою про надання статусу біженців тощо, були передані Державному департаменту у справах національностей та міграції у складі Міністерства юстиції України [6]. Надалі на підставі указу Президента України від 13.09.2001 № 836/2001 на базі цього Департаменту знов було створено Державний комітет України у справах національностей та міграції [7], який проіснував до кінця 2001 року, коли й був ліквідований на підставі постанови Кабінету Міністрів України від 27.12.2001 № 1772 [8]. У березні 2002 року Указом Президента України від 19.03.2002 № 269/2002 знов створено Державний комітет України у справах національностей та мігрантів зі статусом центрального органу виконавчої влади, діяльність якого спрямовувалася і координувалася Кабінетом Міністрів України та якому надавалися повноваження з формування державної політики у сфері забезпечення прав біженців, реалізації такої політики, здійснення управління у зазначеній сфері [9].

Нової реорганізації Державний комітет України у справах національностей та мігрантів зазнав у 2006 році, коли на підставі постанови Кабінету Міністрів України від 08.11.2006 № 1575 на його основі та на основі Державного департаменту у справах релігій було створено Державний комітет України у справах національностей та релігій [10]. Правовий статус нового органу визначався Положенням про Державний комітет України у справах національностей та релігій, затвердженим постановою Кабінету Міністрів України від 14.02.2007 № 201, відповідно до норм якого зазначений комітет визнавався спеціально уповноваженим центральним органом виконавчої влади у справах міграції в межах, визначених законодавством про біженців [11].

Численні реорганізаційні зміни в системі органів виконавчої влади довели необхідність створення єдиного органу, який би зосередив у собі функції у сфері міграції, громадянства та імміграції. Перша спроба створення ДМС України відбулася у 2009 році, коли на підставі постанови Кабінету Міністрів України від 24.06.2009 № 643 утворена Державна міграційна служба України [12], яка проіснувала недовго і була ліквідована у липня 2010 року постановою Кабінету Міністрів України від 07.07.2010 № 559 «Деякі питання державного управління у сфері міграції», при цьому її правонаступником визнавалися: з питань громадянства, реєстрації фізичних осіб та імміграції - Міністерство внутрішніх справ, а з питань міграції, в межах визначених законодавством про біженців, - Державний комітет у справах національностей та релігій [13]. Як слушно вказує В. П. Босий, помилковість ліквідації Державної міграційної служби стала очевидною вже через п'ять 
місяців [14, с. 118-125], і вже у квітні наступного року видано Указ Президента України від 06.04.2011 № 405/2011 «Питання Державної міграційної служби України» [15], в якому визначалися основні завдання, функції та повноваження ДМС України. Зазначений вище указ втратив чинність на підставі Положення про Державну міграційну службу України, затвердженого постановою Кабінету Міністрів України від 20.08.2014 № 360 [16] (далі - Положення № 360), яке на сучасному етапі є основним нормативним актом, що визначає правовий статус вищевказаної служби.

Відповідно до Положення № 360, ДМС України є центральним органом виконавчої влади, діяльність якого спрямовується та координується Кабінетом Міністрів України через Міністра внутрішніх справ і який реалізує державну політику в сферах міграції (імміграції та еміграції), у тому числі протидії нелегальній (незаконній міграції), громадянства, реєстрації фізичних осіб, біженців та інших визначених законодавством категорій мігрантів [16].

Правовий статус ДМС України натепер визначається постановою Кабінету Міністрів України, що $є$ некоректним. О. М. Єфремова з цього приводу зазначила, що права та обов'язки ДМС України не можуть визначатися підзаконними нормативно-правовими актами, оскільки це порушує конституційні норми [17, с. 192-197]. Дійсно, відповідно до ч. 1 ст. 19 Конституції України, органи державної влади та органи місцевого самоврядування, їх посадові особи зобов'язані діяти лише на підставі, в межах повноважень та у спосіб, що передбачені Конституцією та законами України [18]. Наприклад, якщо дослідити правове регулювання прав та обов'язків суб'єктів адміністративно-правового забезпечення статусу біженця, які опосередковано впливають на надання такого статусу, то вони здійснюються як законами «Про державну прикордонну службу України» від 03.04.2003 № 661-IV [19], «Про Службу безпеки України» від 25.03.1991 № 2229-XII [20], так і положеннями, а саме Положенням про Міністерство внутрішніх справ України від 28.10.2015 № 878 [21], Положенням про Міністерство закордонних справ України» від 30.03.2016 № 281 [22]. Причиною такого становища є суттєве реформування системи центральних органів виконавчої влади, внаслідок якого закони, що врегульовували діяльність тих органів виконавчої влади, які діяли до такого реформування, втратили чинність, а нові закони, якими б визначалася компетенція новостворених органів, ще не розроблені та не прийняті. Проте таке становище суперечить Конституції України, отже потрібно якнайшвидше розробити та прийняти Закон України «Про Державну міграційну службу України».

Основним завданням ДМС України є реалізація державної політики у сфері міграції (імміграції та еміграції), в тому числі протидії нелегальній (незаконній) міграції, громадянства, реєстрації фізичних осіб, біженців та інших визначених категорій мігрантів. Отже, вирішення питання про надання статусу біженця є лише одним із завдань ДМС України.

Правовий статус ДМС України, як центрального органу виконавчої влади, крім Положення № 360, визначається ще й Законом України від 17.03.2011 № 3166-VI «Про центральні органи виконавчої влади», відповідно до ст. 16 якого центральні органи виконавчої влади утворюються для виконання окремих функцій з реалізації державної політики як служби, агентства, інспекції, комісії, при цьому як служба центральний орган виконавчої влади у разі, якщо більшість його функцій становлять функції 3 надання адміністративних послуг фізичним та юридичних особам [16]. Отже, якщо врахувати, що ДМС України визначається як служба, то більшість її функцій повинно бути спрямовано на надання адміністративних послуг фізичним та юридичним особам.

У Положенні № 360 функції ДМС України не закріплюються, отже, їх визначення, 3 огляду на тему нашого дослідження, можна здійснити шляхом аналізу повноважень. Так, відповідно до ст. 4 зазначеного Положення, до повноважень ДМС України з надання статусу біженця належать: аналіз проблем біженців, розробка поточних та довгострокових прогнозів із зазначених проблем; оформлення і видача документів для проживання в Україні, а також виїзду за її межі, вилучення таких документів; прийняття рішення про продовження (скорочення) строку тимчасового перебування осіб, що претендують на отримання статусу біженця; ідентифікація осіб, які звернулися із заявами про визнання біженцем; прийняття рішення про визнання іноземців та осіб без громадянства біженцем, про втрату, позбавлення статусу біженця і про скасування рішення про визнання біженцем; зібрання та аналіз інформації про наявність у країнах походження біженців умов, за яких такий захист надається; розгляд скарг на рішення про відмову у прийнятті заяви про визнання біженцем, про відмову в оформленні документів для вирішення питання щодо визнання біженцем і скасування зазначених рішень, 
якщо вони були прийняті 3 порушенням законодавства; вжиття у межах компетенції заходів для сприяння реалізації прав біженців; здійснення оформлення і видача посвідчення біженця, а також інших документів, передбачених законодавством для даних категорій осіб; видача проїзних документів іноземцям, яких було визнано біженцями іншими країнами - учасниками Конвенції про статус біженців 1951 року та/або Протоколу щодо статусу біженців 1967 року; ведення обліку осіб, які отримали або які претендували на отримання статусу біженця на всіх етапах проведення відповідних процедур; здійснення розгляду звернень громадян з питань, пов'язаних із діяльністю ДМС, іï територіальних органів та територіальних підрозділів, підприємств, установ та організацій, що належать до сфери ï управління; здійснення відповідно до закону державного контролю за дотриманням законодавства у сферах міграції (імміграції та еміграції) у тому числі протидії нелегальній (незаконній) міграції, громадянства, біженців та інших визначених законодавством категорій мігрантів у передбачених законодавством випадках, притягнення порушників до адміністративної відповідальності; оформлення, видача, обмін, пересилання, вилучення, повернення державі, знищення документів 3 безконтактним електронним носієм; надання адміністративних послуг відповідно до закону [16]. Виходячи з перерахованого, функції ДМС України у питаннях, пов'язаних із біженцями, можна визначити як надання адміністративних послуг 3 надання іноземцям та особам без громадянства статусу біженця.

\section{Висновки}

Підсумовуючи зазначене, констатуємо що тривалий розвиток та реорганізація державних органів виконавчої влади, які відбулися з 1993 до 2014 років, довели необхідність створення та функціонування ДМС України як центрального органу виконавчої влади, який забезпечує реалізацію державної політики у сфері міграції і є основним органом, що безпосередньо здійснює адміністративні послуги з надання іноземцям та особам без громадянства статусу біженця.

\section{Список використаних джерел:}

1. Про оптимізацію системи центральних органів виконавчої влади: Указ Президента України від 09.12.2010 № 1085/2010. URL: https:// zakon.rada.gov.ua/laws/show/1085/2010. (дата звернення: 20.03.2020).

2. Про Міністерство України у справах національностей та міграції : Указ Пре- зидента України від 26.04.1993 № 145. URL: https://zakon.rada.gov.ua/laws/show/145/93. (дата звернення: 20.03.2020).

3. Питання Міністерства України у справах національностей та міграції : постанова Кабінету Міністрів України від 26.06.1993 № 487. URL: https://zakon.rada.gov.ua/laws/show/487-93\%D0\%BF. (дата звернення: 20.03.2020).

4. Про зміни в системі центральних органів виконавчої влади України : Указ Президента України від 26.07.1996 № 596. URL: https://zakon.rada.gov.ua/laws/show/596/96. (дата звернення: 20.03.2020).

5. Положення про Державний комітет України у справах національностей та міграції : Указ Президента України від 28.10.1996 № 1001/96. URL: https://zakon.rada.gov.ua/laws/show/1001/96. (дата звернення: 20.03.2020)

6. Про зміни у структурі центральних органів виконавчої влади : Указ Президента України від 15.12.1999 № 1573/99. URL: https://zakon.rada.gov.ua/laws/show/1573/99. (дата звернення: 20.03.2020).

7. Про Державний комітет України у справах національностей та міграції : Указ Президента України від 13.09.2001 № 836/2001. URL: http://search.ligazakon.ua/1_doc2.nsf/link1/ U836 01.html. (дата звернення: 20.03.2020).

8. Про ліквідацію Державного департаменту у справах національностей та міграції : постанова Кабінету Міністрів від 27.12.2001 № 1772. URL: https://zakon.rada.gov.ua/laws/show/1772-2001\%D0\%BF. (дата звернення: 20.03.2020).

9. Про Положення про Державний комітет України у справах національностей та міграції : Указ Президента України від 19.03.2002 № 269/2002. URL: https://zakon.rada.gov.ua/laws/show/269/2002 (дата звернення: 20.03.2020).

10. Про утворення Державного комітету України у справах національностей та релігій : постанова Кабінету Міністрів України від 08.11.2006 № 1575. URL: https://zakon.rada.gov.ua/ laws/show/1575-2006-\%D0\%BF (дата звернення: 20.03.2020).

11. Про затвердження Положення про Державний комітет України у справах національностей та релігій : постанова Кабінету Міністрів України від 14.02.2007 № 201. URL: https://zakon.rada.gov.ua/laws/show/201-2007$\% \mathrm{D} 0 \% \mathrm{BF}$ (дата звернення: 20.03.2020).

12. Про утворення Державної міграційної служби України : постанова Кабінету Міністрів України від 24.06.2009 № 643. URL: https://zakon.rada.gov.ua/laws/show/643-2009\%D0\%BF (дата звернення: 20.03.2020).

13. Деякі питання державного управління у сфері міграції : постанова Кабінету Міністрів України від 07.07.2010 № 559. URL: https://zakon.rada.gov.ua/laws/show/559-2010\%D0\%BF (дата звернення: 20.03.2020).

14. Босий В. П. Інституційно-правова система забезпечення прав біженці в Україні. Наукові праці МАУП. 2015. Вип. 44(1). С. 118-125. 
15. Положення про Державну міграційну службу України : Указ Президента України від 06.04.2011 № 405/2011. URL: https://zakon.rada.gov.ua/laws/show/405/ 2011 (дата звернення: 20.03.2020).

16. Положення про Державну міграційну службу України : постанова Кабінету Міністрів України від 20.08.2014 № 360. URL: https://zakon.rada.gov.ua/laws/show/360-2014\% D0\%BF (дата звернення: 20.03.2020).

17. Єфремова М. О. Адміністративно-правовий статус державної міграційної служби України: питання теорії та практики. Науковий вісник Херсонського державного університету. Серія «Право». 2015. Вип. 1. Т. 2. С. 192-197.

18. Конституція України. URL: https:// zakon.rada.gov.ua/laws/show/254\%D0\%BA/96\%D0\%B2\%D1\%80 (дата звернення: 20.03.2020).

19. Про державну прикордонну службу Украіни : Закон України від 03.04.2003 № 661-IV. URL: https://zakon.rada.gov.ua/laws/show/661-15 (дата звернення: 20.03.2020).

20. Про Службу безпеки України : Закон України від 25.03.1991 № 2229-XII. URL: https:// zakon.rada.gov.ua/laws/show/2229-12 (дата звернення: 20.03.2020).

21. Положення про Міністерство внутрішніх справ України: постанова Кабінету Міністрів України від 28.10.2015 № 878. URL https://zakon.rada.gov.ua/laws/show/878-2015-п. (дата звернення 20.03.2020).

22. Положенням про Міністерство закордонних справ України : постанова Кабінету Міністрів України від 30.03.2016 № 281. URL: https://zakon.rada.gov.ua/laws/show/281-2016-п. (дата звернення: 20.03.2020).

23. Про центральні органи виконавчої влади : Закон України від 17.03.2011 № 3166-VI URL: https://zakon.rada.gov.ua/laws/show/3166-17. (дата звернення: 20.03.2020).

Dmytro Hurin. Legal status of the state migration service in ensuring the implementation of migration state policy

The article examines the development and reorganization of state executive bodies, which have been entrusted with the functions of implementation of state migration policy, and the legal status of the state migration service as the central body of executive power, which ensures the implementation of state migration policy in Ukraine.

It has been determined that the reorganization of state authorities on the implementation of state policy in the field of migration in Ukraine has been going on for more than 10 years and indicates the need for the creation and effective functioning of a separate state body that would concentrate its functions in the field of migration, citizenship, and immigration. The State Migration Service of Ukraine became such an authority.

Attention is drawn to a comparative study of the legal status of public authorities, which during the reorganization had the authority to implement state policies in the areas of migration (immigration and emigration), including combating illegal (illegal migration), citizenship, registration of individuals and refugees, refugee's legislation of categories of migrants.

The rights and responsibilities of the LCA of Ukraine as a central executive body, whose activity is directed and coordinated by the Cabinet of Ministers of Ukraine through the Minister of Internal Affairs and which implements the state policy in the fields of migration (immigration and emigration), including combating illegal (illegal migration), citizenship, registration of individuals, refugees and other categories of migrants defined by law.

The necessity of elaboration of the Law of Ukraine "On State Migration Service" is substantiated. It is noted that the LCA of Ukraine is defined as a service, so most of its functions should be directed to the provision of administrative services to individuals and legal entities. By examining the authority of the Ukrainian VHS as a refugee, it is established that the VMS functions in refugee-related issues can be defined as providing administrative services for granting refugee status and stateless status to foreigners and stateless persons.

Summarizing the above, we note that the prolonged development and reorganization of state executive bodies, which took place from 1993 to 2014, proved the need for the creation and functioning of the LCA of Ukraine as a central executive body that ensures the implementation of state migration policy, and is the main body, which directly provides administrative services for the granting of refugee status to foreigners and stateless persons.

Key words: legal status, public authorities, migration policy, migration service, refugee, legal regulation, status granted. 